\section{Nationwide Branch Banking and the Presence of Large Banks in Rural Areas}

\section{R. Alton Gilbert}

overnment restrictions on the rights of banks to open branches and establish offices across state lines have been relaxed throughout the nation since the early 1980s. During the 1980s and early 1990s, many states relaxed controls over branching by banks located within their borders, and almost all of them permitted some form of regional interstate banking through acquisitions of banks by holding companies (Berger, et al, 1995, pp. 188-89). Federal legislation enacted in 1994, the Riegle-Neal Interstate Banking and Branching Efficiency Act, permitted bank holding companies to buy banks located throughout the nation beginning in the fall of 1995, and permitted nationwide branching as of June 1997. ${ }^{1}$

This article examines the extent to which large banking organizations have expanded their presence in rural areas during this period of relaxation in constraints on multioffice banking (acquisitions of banks by holding companies and branching by banks). The effects of these changes in banking regulations on rural areas may be different from the effects on urban areas. Large banking organizations may have bypassed rural areas in their attempts to grow rapidly by buying urban banks. There is reason to believe, however, that nationwide branch banking eventually will lead to a major presence of large banks in rural areas throughout the nation. During the early 1980s, prior to regional or national interstate banking, the presence of large banking organizations in rural areas depended on state branching restrictions (Gilbert, 1997). Large banks were the major organizations in the rural counties of the states that permitted statewide branching. In contrast, large organizations had much more limited roles in the rural areas of states that had placed more restrictions on bank branching. Large organizations had the interest and ability to be major participants in the rural banking markets of the states that had given banks the greatest freedom to expand through branching.

Some people have expressed concern that a greater presence of large banks in rural areas might have adverse effects on rural communities, by reducing the supply of credit to rural residents (Neff and Ellinger, 1996; and Featherstone, 1996). For this reason, it is important to understand the extent to which large banks have increased their presence in rural areas. In evaluating the implications of these trends for rural communities, however, it also is important to consider reasons why the entry of large banking organizations may have positive effects on rural communities. The next section surveys the studies that have implications for the effects of entry by large banking organizations on rural communities. The following sections present the data on the presence of large organizations in rural areas.

\section{POSSIBLE EFFECTS OF LARGE BANK- ING ORGANIZATIONS ON RURAL BANKING MARKETS}

There has long been a populist notion in the United States that banking consolidation is a threat to the viability of small businesses, including rural small businesses. This view is based on several assumptions about the financing of small businesses and the lending behavior of large banks. Credit from banks is assumed to be more important for small businesses than for large businesses, since large businesses can raise funds directly in the financial markets. In addition, small businesses are assumed to get their financial services from banks with offices located in their communities. Finally, large banks are assumed to use the funds they raise through their rural branches to invest outside of rural areas.

\footnotetext{
${ }^{1}$ The Riegle-Neal Act gave each state the right to opt out of nationwide branch banking within a limited period of time. The states were not permitted to opt out of nationwide interstate banking through acquisitions of banks by bank holding companies. As of September 1995, bank holding companies located throughout the United States could enter any other state by buying banks or other holding companies. If a state opted out of nationwide branch banking, the banks purchased by out-of-state holding companies could not be converted to branches of banks headquartered in other states. Only Texas and Montana chose to opt out of nationwide branch banking. In 1999, the state of Texas enacted legislation that effectively reversed its earlier action to opt out of nationwide branch banking.
} 
There are reasons to believe, however, that the residents of rural communities actually benefit when large banks enter their communities. Relaxation of branching restrictions that had constrained expansion by large organizations may increase the availability of banking offices in rural areas. A larger banking organization can provide a wider range of financial services, and large banks can make loans that would exceed the lending limits of the small, locally owned banks. Large banks may operate more efficiently than the small, locally owned banks located in rural communities, and they may stimulate competition in rural areas when they acquire existing banks or open new offices. Finally, entry by large banking organizations may make rural communities less vulnerable to disruption in economic activity resulting from failure by small, locally owned banks.

\section{Studies of Lending by Large Banks to Small Businesses}

Some of the assumptions that underlie the populist notion about the adverse effects of large banks on small businesses are supported by evidence Bank credit is more important for small businesses than for larger businesses (Berger and Udell, 1998). Surveys indicate that most small firms get their banking services from banks with offices located in their own communities (Cole and Wolken, 1995; Cole, Wolken, and Woodburn, 1996; and Elliehausen and Wolken, 1990). While the results of these surveys do not rule out the possibility that small firms could have obtained financial services from other firms located in more distant cities, the results are consistent with the view that small firms tend to be dependent on local banks for financial services. Small businesses located in rural areas that are dependent on local banks for financing tend to have fewer options than small firms located in urban areas because rural areas, with their relatively low population density, tend to have relatively few banks.

The remaining assumption involves the lending by large banks to small businesses. Recently, there have been many studies of this issue, which are summarized by Berger, Demsetz, and Strahan (1999). These studies do not yield a clear conclusion about the effects of banking-industry consolidation on the access of small businesses to credit. One recent study illustrates some of the challenges involved in quantifying the effects of banking consolidation on the access of small businesses to credit. Berger, et al, (1998) identified "huge" banks as those with total assets over $\$ 10$ billion. They found that while acquisitions of relatively small banks by huge banks reduced lending to small businesses, these effects tended to be offset by increases in lending to small businesses by other banks with offices in the market areas where the merging banks also had their offices. Thus, banks not involved in the consolidations tended to increase their lending to small businesses, offsetting the direct negative effects of the consolidations on small business lending.

Most studies of banking consolidation and lending to small businesses use banking data. Jayartne and Wolken (1999), in contrast, used data from a survey of small firms. They found that various measures of the access of small firms to credit were not correlated with the share of banking assets in their communities at small banks. Their results tend to undermine the conclusion that banking consolidation will restrict access to credit for small firms.

Only a few studies in this literature focus on rural areas. Keeton (1996) found some evidence that acquisitions of rural banks by out-of-state organizations tended to reduce their lending to small businesses. Lawrence and Klugman (1991) found only one significant effect of the acquisition of rural banks by outof-state banking organizations: a rise in the ratio of loans to deposits at the acquired rural banks. Lawrence and Klugman suggested that these increases in loanto-deposit ratios reflected loans originated by other subsidiaries of the banking organizations that were placed on the books of their newly acquired rural bank subsidiaries.

Gilbert and Belongia (1988) found that among banks located in rural areas, lending to farmers as a percentage of their total loans was related inversely to the size of their parent organizations. They interpreted these results as evidence that the opportunities for rural banks to diversify their loan portfolios by industry were positively related to the size of their parent organizations. Investment options of locally owned banks tended to be limited to loans to local firms and securities, whereas the rural banks that were subsidiaries of large organizations could participate in loans originated by their affiliates located in other areas.

The results in Gilbert and Belongia (1988) could be interpreted as indicating that banking consolidation will tend to restrict the access of farmers to credit from banks. The results in Featherstone (1996), however, do not support this conclusion. He found that, on average, rural banks did not reduce the percentages of their loans invested in agriculture during periods 
of three years after larger banks acquired them. He found a positive association between the agricultural loan ratios of the acquired banks and the acquiring banks. The relatively large banks that specialized in agricultural lending sought smaller banks to acquire that also specialized in the same industry.

\section{Branching Restrictions and the Availability of Banking Offices}

Several studies have examined the association between branching restrictions and the availability of banking offices in rural areas. Calomiris (1993) presented historic evidence that state laws permitting branching facilitated access to banking services by residents in areas far from large cities. Evanoff (1988), who summarized several of the early studies, estimated the determinants of the number of banking offices per square mile in rural counties and metropolitan areas. Evanoff found that permission for limited branching increased the number of banking offices per square mile in rural areas, relative to unit-banking restrictions. Statewide branching, in contrast, did not increase the number of banking offices per square mile in rural areas. Gunther (1997) found that relaxation of branching restrictions increased the availability of banking services for rural residents.

\section{Banking Structure and Local Economic Growth}

One recent study examined the direct effects of bank consolidation on regional economic growth, rather than inferring economic effects from the influence of bank consolidation on lending to small firms. Jayartne and Strahan (1996) found that growth of income at the state level tended to increase when states relaxed the branching laws for banks within their borders. They argued that liberalizing branching regulations stimulated state economic growth by giving the banking industry greater freedom to direct credit to the borrowers who could put it to the best use

The results reported by Jayartne and Strahan do not have clear implications for the effects of branching restrictions on rural economic growth, since their study estimated the determinants of economic growth at the state level. One of their conclusions, however, has implications for the mechanism through which relaxation of branching restrictions might stimulate economic growth in rural communities. They concluded that the positive effect of relaxing branching restrictions on state economic growth did not depend entirely on the amount of lending, but rather upon the efficiency of banks in allocating credit to the borrowers who could use the funds the most productively. It is possible that large banking organizations could stimulate economic growth in rural areas by reallocating credit to the borrowers in rural areas who could use the funds most productively. The historic information in Calomiris (1993) also is relevant for the effects of branch banking on rural economic growth; he found that branch banking facilitated the financial integration of the United States.

Another aspect of bank structure and local economic growth involves the adverse effects of failures by small, locally owned banks on economic activity in rural areas. Restrictions on multioffice banking (the ownership of banks by holding companies and bank branching) tend to create a banking industry in which rural residents are served by small, locally owned banks, which cannot diversify their risk geographically. The residents of rural areas in states with such restrictions on multioffice banking tend to rely on the small, locally owned banks for financial services. There is evidence that failures of small, locally owned banks tend to have adverse effects on economic activity in rural communities (Gilbert and Kochin, 1989).

The literature on the effects of entry by large banking organizations into rural banking markets does not attempt to determine whether the offices of large banking organizations operate more efficiently than the small, rural banks with which they compete. In addition, these studies do not examine the effects of entry by large organizations on the competitive behavior of rural banks.

\section{MEASURING THE PRESENCE OF LARGE BANKING ORGANIZATIONS IN RURAL AREAS}

Some definitions are necessary. First, what is a rural area? This article identifies rural areas as the counties outside of metropolitan areas as of June 1998. Identifying the same group of counties as rural areas over time avoids a possible distortion of the data: changes in measures of the presence of large banking organizations in rural areas that reflect changes in the counties classified as rural.

Next, what do we mean by a banking organization? A bank that is not a subsidiary of a holding company is classified as a separate organization. If a bank is a subsidiary of a holding company, the holding company is the banking organization. 
Having defined banking organizations, a related issue involves identifying large organizations. The criteria for identifying large organizations are derived from the recent studies discussed above that examine the effects of banking consolidation on small-business lending. In these studies, the size of the large organizations ranges from $\$ 3$ billion or more in total assets up to $\$ 10$ billion or more This article uses two criteria for identifying large banking organizations: those with total deposits of $\$ 5$ billion or more and those with total deposits of $\$ 10$ billion or more as of June 1998. A third group also includes smaller, regional organizations: those with total deposits of $\$ 1$ billion or more as of June 1998. This third group of regional organizations is useful for this study because large organizations have tended to acquire offices in rural areas by acquiring smaller, regional organizations that al ready had established their networks of offices in rural areas. In tracing the movement of large organizations into rural areas during recent years, therefore, it is helpful to trace the movement of regional organizations into rural areas during earlier years.

This study measures the size of banking organizations in terms of deposits because all of the data are derived from the Summary of Deposits, which are limited to deposit liabilities. For some of the years covered by this study, there are technical problems in linking the data from the Summary of Deposits to that of the call reports, which include data on the total assets of banks.

The critical levels of total deposits for identifying regional and large organizations are indexed over time to account for growth of total deposits at commercial banks. The index number equals 100 for 1998, is less than 100 for prior years, and greater than 100 in 1999. To illustrate the indexing of the critical deposit levels, the deposit level in 1980 associated with the size category of $\$ 10$ billion equals: $\$ 10$ billion, times total deposits of the banking industry in June 1980, divided by total deposits in June 1998.

This method of indexing levels of deposits is useful for separating the effects of growth in the total deposits of the banking industry from the effects of consolidation. To illustrate, consider the following measure of the presence of large banking institutions in rural areas: the percentage of residents in the rural counties of a state who resided in the counties where large organizations had offices. Suppose that over time no offices were opened or closed, no offices changed ownership among banking organizations, the deposits of each office in the nation grew at the same rate, and the population of each rural county remained unchanged over time. Under these assumptions, there would be no changes over time in the percentage of rural residents who lived in areas where regional and large organizations had offices.

The article focuses on three questions in measuring the presence of large banking organizations in rural areas. First, to what extent did the residents of rural communities live in areas served by the offices of large organizations? The measure designed to answer this question is the percentage of residents in rural areas located in counties in which large organizations had at least one office In calculating this percentage, the denominator is the total population of rural counties in a state or region, and the numerator is the sum of the population in these rural counties where large banking organizations had at least one office.

The second question: To what extent did the residents of rural communities live in areas where large organizations were the major banks? The measure chosen to answer this question is the percentage of the rural population who resided in counties in which large organizations accounted for over half of local deposits (the deposits at offices in the counties). The denominator of this percentage is the total population of rural counties in a state or region, and the numerator is the sum of the population in these rural counties where the share of deposits in the offices large banking organizations exceeded 50 percent.

This article traces changes in these measures of the presence of large banking organizations in rural areas by examining a series of "snapshots" of their offices in rural areas once each year. The article does not trace the series of transactions, such as buying banks or selling individual branches, that produced the changes in the presence of large banking organizations in rural counties. The annual snapshots of the presence of large organizations in rural areas are derived from the Summary of Deposits; banks report their deposit liabilities in various categories at each office, as of June each year. This article uses the data on the total deposits of each office. The latest data available are as of June 1999. ${ }^{2}$

\footnotetext{
2 The measures of the presence of large banking organizations also reflect data on the population of each rural county as of each year. The latest data on population at the county level are as of 1998. In deriving measures for the presence of large banking organizations in rural counties as of June 1999, the population of each county in 1999 is assumed to be the same as its population in 1998.
} 


\section{Residents of Rural Counties Where Large Banking Organizations Had Offices}

Among people in rural counties, the percentage in counties with at least one bank with total deposits (indexed to 1998) greater than:

\begin{tabular}{|c|c|c|c|c|c|c|c|}
\hline Region & \$1 billion & $\$ 5$ billion & $\$ 10$ billion & Region & $\$ 1$ billion & $\$ 5$ billion & $\$ 10$ billion \\
\hline \multicolumn{4}{|c|}{ New England } & \multicolumn{4}{|c|}{ Pacific Northwest } \\
\hline 1980 & 54.2 & 0.0 & 0.0 & 1980 & 88.7 & 79.0 & 70.3 \\
\hline 1995 & 97.9 & 82.6 & 82.6 & 1995 & 95.1 & 91.8 & 89.2 \\
\hline 1998 & 96.7 & 83.1 & 83.1 & 1998 & 95.4 & 89.3 & 89.3 \\
\hline \multirow[t]{2}{*}{1999} & 96.7 & 83.1 & 83.1 & 1999 & 95.4 & 89.2 & 89.2 \\
\hline & & & & \multicolumn{4}{|c|}{ Pacific Southwest } \\
\hline \multicolumn{4}{|c|}{ Middle Atlantic } & 1980 & 79.6 & 59.0 & 54.4 \\
\hline 1980 & 67.9 & 49.3 & 43.2 & 1995 & 91.3 & 89.5 & 86.9 \\
\hline 1995 & 98.2 & 96.7 & 96.7 & 1998 & 94.7 & 92.5 & 83.2 \\
\hline 1998 & 98.7 & 96.1 & 93.3 & 1999 & 95.5 & 93.2 & 93.2 \\
\hline
\end{tabular}

\section{South Atlantic}

$\begin{array}{lllr}1980 & 60.1 & 30.0 & 0.0 \\ 1995 & 88.3 & 85.4 & 80.4 \\ 1998 & 89.3 & 84.9 & 81.0 \\ 1999 & 90.0 & 84.2 & 81.0\end{array}$

\section{East South Central}

$\begin{array}{rrrr}1980 & 21.7 & 6.9 & 0.0 \\ 1995 & 76.1 & 63.5 & 35.8 \\ 1998 & 79.7 & 68.2 & 65.9 \\ 1999 & 84.0 & 77.6 & 75.7\end{array}$

\section{West South Central}

$\begin{array}{rrrr}1980 & 11.1 & 4.3 & 3.7 \\ 1995 & 57.1 & 39.8 & 27.6 \\ 1998 & 64.5 & 49.2 & 40.5 \\ 1999 & 68.3 & 50.1 & 50.1\end{array}$

\section{East North Central}

$\begin{array}{llll}1980 & 42.6 & 26.1 & 6.0 \\ 1995 & 91.2 & 80.1 & 80.1 \\ 1998 & 92.3 & 79.4 & 77.2 \\ 1999 & 94.5 & 84.3 & 81.1\end{array}$

\section{West North Central}

$\begin{array}{llll}1980 & 45.5 & 30.3 & 21.7 \\ 1995 & 66.4 & 53.3 & 39.4 \\ 1998 & 72.5 & 65.2 & 61.0 \\ 1999 & 73.3 & 66.4 & 63.3\end{array}$

\section{States in regions: \\ New England * Connecticut, *Maine, Massachusetts, \\ * New Hampshire, *Rhode Island, and \\ * Vermont \\ Middle Atlantic * New Jersey, *New York, and Pennsylvania \\ South Atlantic * Delaware, Florida, Georgia, \\ * Maryland, *North Carolina, *South Carolina, Virginia, and West Virginia \\ East South Central Alabama, Kentucky, Mississippi, and Tennessee \\ West South Central Arkansas, Louisiana, Oklahoma, and Texas \\ East North Central Illinois, Indiana, Michigan, Ohio, and Wisconsin \\ West North Central lowa, Kansas, Minnesota, Missouri, Nebraska, North Dakota, and \\ * South Dakota \\ Pacific Northwest $\quad *$ Alaska, *Idaho, Montana, *Oregon, \\ * Washington, and Wyoming \\ Pacific Southwest * Arizona, *California, Colorado, \\ * Hawaii, *Nevada, New Mexico, and Utah}

Note: States preceded by an asterisk permitted statewide branching in 1980, subject to various restrictions on branching in the communities where banks had their headquarters. 


\section{Table 2}

\section{Residents of Rural Counties Where Large Organizations Were the Major Banks}

Among people in rural counties, percentage in counties in which banking organizations in the following size ranges accounted for at least half of local deposits

Total deposits (indexed to 1998) greater than:

\begin{tabular}{|c|c|c|c|c|c|c|c|}
\hline Region & $\$ 1$ billion & $\$ 5$ billion & $\$ 10$ billion & Region & $\$ 1$ billion & $\$ 5$ billion & $\$ 10$ billion \\
\hline \multicolumn{4}{|c|}{ New England } & \multicolumn{4}{|c|}{ West North Central } \\
\hline 1980 & 8.0 & 0.0 & 0.0 & 1980 & 15.1 & 8.6 & 7.4 \\
\hline 1995 & 39.4 & 1.5 & 1.5 & 1995 & 21.2 & 10.0 & 6.7 \\
\hline 1998 & 50.6 & 23.8 & 0.0 & 1998 & 21.9 & 10.4 & 6.2 \\
\hline 1999 & 50.6 & 27.9 & 0.0 & 1999 & 21.0 & 9.3 & 4.7 \\
\hline \multicolumn{4}{|c|}{ Middle Atlantic } & \multicolumn{4}{|c|}{ Pacific Northwest } \\
\hline 1980 & 24.7 & 1.6 & 1.6 & 1980 & 69.9 & 47.9 & 13.4 \\
\hline 1995 & 54.1 & 32.3 & 32.3 & 1995 & 72.5 & 61.4 & 38.0 \\
\hline 1998 & 60.3 & 22.4 & 16.8 & 1998 & 75.4 & 56.3 & 54.9 \\
\hline 1999 & 60.5 & 17.8 & 17.8 & 1999 & 67.2 & 52.1 & 52.1 \\
\hline \multicolumn{4}{|c|}{ South Atlantic } & \multicolumn{4}{|c|}{ Pacific Southwest } \\
\hline 1980 & 36.6 & 4.7 & 0.0 & 1980 & 65.7 & 48.9 & 43.9 \\
\hline 1995 & 67.4 & 50.7 & 32.2 & 1995 & 69.6 & 59.9 & 48.6 \\
\hline 1998 & 68.0 & 55.5 & 31.6 & 1998 & 66.4 & 62.7 & 45.2 \\
\hline 1999 & 68.1 & 54.4 & 32.0 & 1999 & 66.7 & 62.3 & 55.9 \\
\hline
\end{tabular}

\section{East South Central}

$\begin{array}{rrrr}1980 & 5.8 & 0.0 & 0.0 \\ 1995 & 36.6 & 18.5 & 7.5 \\ 1998 & 35.9 & 17.6 & 15.1 \\ 1999 & 38.4 & 21.2 & 18.7\end{array}$

West South Central

$\begin{array}{lrll}1980 & 3.4 & 1.7 & 1.2 \\ 1995 & 12.5 & 3.7 & 2.3 \\ 1998 & 19.0 & 9.7 & 5.0 \\ 1999 & 16.9 & 6.8 & 6.5\end{array}$

\section{East North Central}

$\begin{array}{rrrr}1980 & 13.1 & 5.8 & 0.4 \\ 1995 & 39.3 & 22.1 & 21.1 \\ 1998 & 43.9 & 20.3 & 19.9 \\ 1999 & 38.8 & 17.7 & 15.0\end{array}$


Tables 1 and 2 report the percentages used in answering these two questions about the presence of large banks in rural areas. Changes in these measures over time reflect the shifts of population among rural counties as well as the changes in the location of the offices of large banking organizations. The percentages were calculated again with the population of each rural county fixed during each year at its 1980 level to determine the degree to which patterns in these tables reflect shifts of population among rural counties. Freezing the population of each county at its level as of 1980 had only small effects on the results reported in Tables 1 and 2 . Of the 54 percentages presented in Tables 1 and 2 for 1998, only six would change by more than two percentage points, and only two by more than three percentage points. Conclusions derived from these tables reflect changes in the geographic location of the offices of large banking organizations, not shifts of population among rural counties.

The third question: Is the presence of large organizations correlated with the demographic characteristics of rural areas? The article examines whether there is an association between the population density of rural counties and the presence of large organizations. If the rural offices of large organizations tend to be located in the counties with relatively high-population density, then low-population density would appear to be an effective barrier to entry by large banking organizations.

\section{THE RESULTS}

Table 1 examines trends in the percentage of rural residents in each of the nine census regions who lived in the rural counties where large banking organizations had offices during June of 1980, 1995, 1998, and 1999. The same counties are identified as rural during each of these months: those located outside of metropolitan areas as of June 1998. These are important dates in the relaxation of geographic restrictions on multioffice banking. In June 1980, most states permitted some form of acquisitions of banks by holding companies, but the holding companies were not permitted to acquire banks across state lines. In addition, most states did not permit banks to branch throughout their borders. Between 1980 and 1995, almost all states permitted some form of interstate banking through acquisitions by holding companies, and by June 1995, most states had permitted statewide branching. In addition, June 1995 represents the end of regional restrictions on interstate banking; federal legislation permitted nationwide interstate banking through acquisitions by holding companies as of September 1995. June 1998 is one year after federal legislation permitted nationwide branch banking, and June 1999 is two years after this major change in our nation's banking regulations.

\section{Rural Residents in Areas Where Large Banking Organizations Had Offices}

Patterns in Table 1 indicate that regulations on branch banking have been an important determinant of the presence of large organizations in rural areas. The states that permitted statewide branching during 1980 were concentrated on the East Coast and in the West. In the four regions in the central section of the nation, only one state permitted statewide branching during 1980 (South Dakota). Table 1 indicates that during 1980 the percentages of rural residents who lived in counties with offices of large organizations were the highest in the West and East Coast states.

Table 1 also reveals that the various regions have become more similar since 1980 in terms of the presence of large banking organizations in rural counties. During 1980, the percentages of rural residents in counties with at least one office of a large organization (indexed to $\$ 10$ billion as of 1998) were 6 percent, or less, in five of the nine census regions and greater than 40 percent in three of the regions. By 1999 these percentages were above 50 percent in each region, and above 75 percent in all but two regions.

Much of the increase in the presence of regional banking organizations (total deposits indexed to $\$ 1$ billion or more) after 1980 had occurred by June 1995, prior to the implementation of nationwide interstate banking. In the East South Central region, for instance, the percentage of rural residents in counties with at least one office of an organization with total deposits indexed to $\$ 1$ billion or more rose from 22 percent in 1980 to 76 percent in 1995. Nationwide interstate banking boosted this percentage to 84 percent by 1999. In the West South Central region, this percentage rose from 11 percent in 1980 to 57 percent in 1995, and then to 68 percent in 1999. Thus, much of this spread of organizations with total deposits indexed to $\$ 1$ billion or more into rural counties occurred through a combination of relaxation of restrictions on intrastate branching and regional interstate banking, not nationwide interstate banking.

Figure 1 illustrates with maps the timing of the spread of regional banking organizations into rural 


\section{Figure 1a}

\section{Presence of Regional Banking Organizations in Rural Counties}

1980

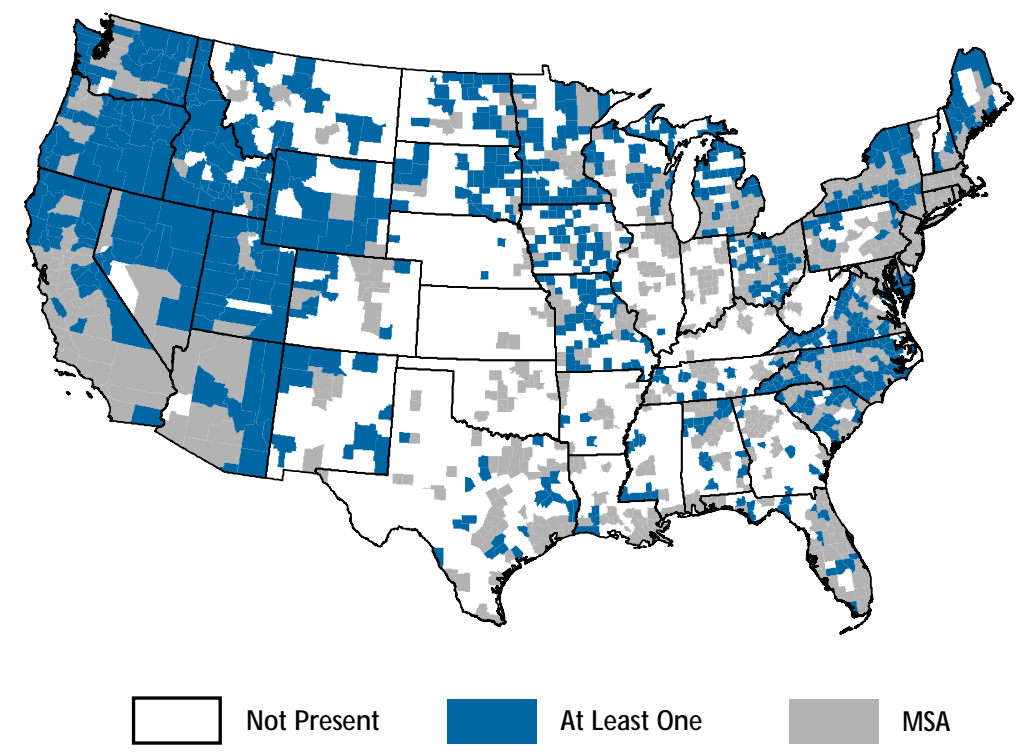

Note: Regional banking organizations are those with total deposits indexed to $\$ 1$ billion or more as of June 1998.

counties since 1980. The areas in blue are the rural counties with at least one office of an organization with total deposits indexed to $\$ 1$ billion or more. These maps show a substantial expansion of the counties marked in blue between 1980 and 1995, but there was not as much change between 1995 and 1999.

In contrast to these results for regional organizations, nationwide interstate banking has had a large impact on the presence of large banking organizations in rural counties. In the East South Central region, for instance, the percentage of rural residents in counties with offices of organizations with total deposits indexed to $\$ 10$ billion or more rose from zero in 1980 to 36 percent by June 1995, and to 76 percent by June 1999. There al so was a large increase in this percentage in the West North Central region between 1995 and 1999.

Figure 2 illustrates the spread of the offices of large organizations (total deposits indexed to $\$ 10$ billion or more). The large expansion of the areas marked in blue in Figure 2 between 1995 (Figure 2b) and 1999 (Figure 2c) reflects the acquisitions of regional organizations by larger organizations under nationwide interstate banking. The large organizations increased their ownership of offices in rural areas as they acquired smaller, regional organizations that had established networks of rural banking offices prior to the fall of 1995, when federal legislation permitted nationwide interstate banking.

\section{Rural Residents in Areas Where Large Banks Were the Major Organizations \\ Have large banking organizations tended to} become the major banking organizations in the rural counties where they have acquired offices in recent years? Or do smaller banks continue to account for substantial shares of deposits in rural counties? Table 2 provides some answers to these questions. As in Table 1, the counties identified as rural during each year were those that were located outside of metropolitan areas in June 1998. As of June 1999, the Pacific Northwest and the Pacific Southwest had the highest concentrations of rural residents in counties where large organizations (total deposits indexed 


\section{Figure 1b}

\section{5}

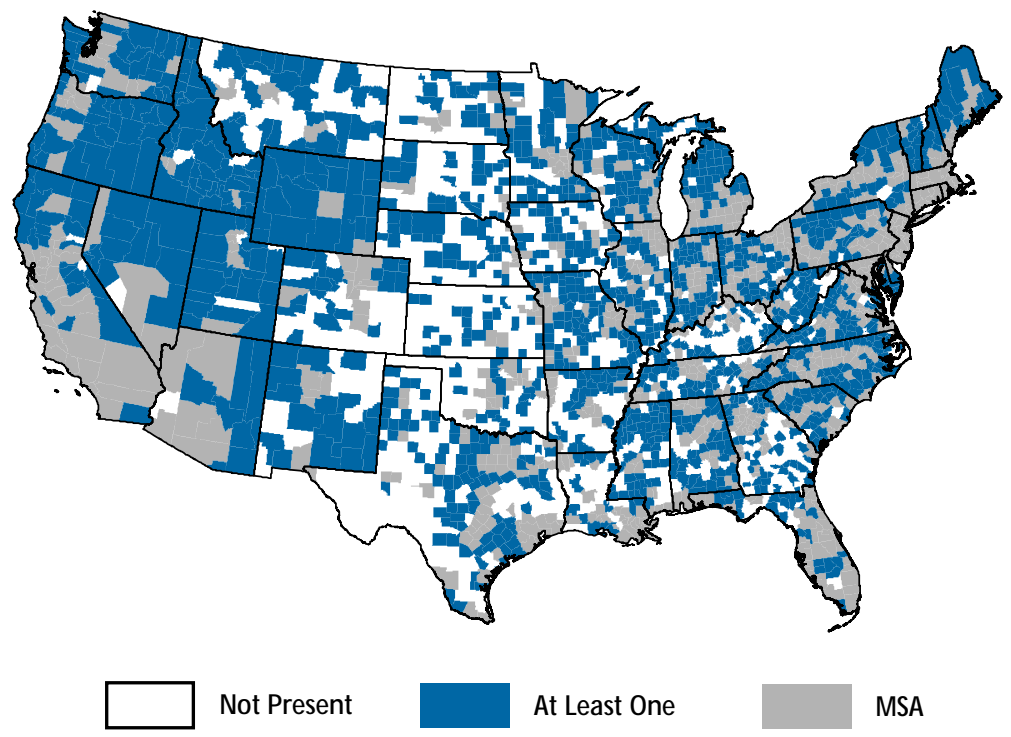

Note: Regional banking organizations are those with total deposits indexed to $\$ 1$ billion or more as of June 1998.

to $\$ 10$ billion as of 1998) accounted for half or more of local deposits. These regions also had the highest percentages during 1980. In six of the nine regions, in contrast, less than 20 percent of rural residents lived in counties where large organizations accounted for half or more of local deposits during June 1999. Relatively small banks continue to be the major organization in most of the rural counties where large organizations have established offices in recent years. In some of the regions, the percentages of rural residents in counties where large organizations account for half or more of local deposits have actually declined since 1995.

Figure 3 presents another perspective on the role of relatively small banking organizations in rural counties. In Figure 3a, rural counties are marked in blue if the organizations with total deposits in excess of $\$ 10$ billion accounted for half or more of local deposits during 1999. Reflecting the patterns in Table 2, the counties marked in blue in Figure 3a tend to be on the east and west coasts-in the states that had permitted statewide branching for many years prior to 1980. Even in the counties marked in blue in Figure 3a, however, large organizations do not account for all of the local deposits. The counties marked in blue in Figure 3b are those where large organizations accounted for 90 percent or more of local deposits. The few rural counties where large organizations had such dominant shares of local deposits were located in the Western states. The contrast between Figures 3a and 3b indicates that in most counties where large organizations accounted for half or more of local deposits, smaller organizations also accounted for substantial shares of local deposits.

\section{Population Density and the Presence of Large Organizations in Rural Areas}

The presence of large banking organizations in rural areas may depend on the demographic characteristics of the rural areas. This article focuses on the differences among rural counties in their population density. Some rural areas have population density close to that of counties in metropolitan areas, whereas other rural counties have much lower population density. If large banking organizations 


\section{Figure 1c}

1999

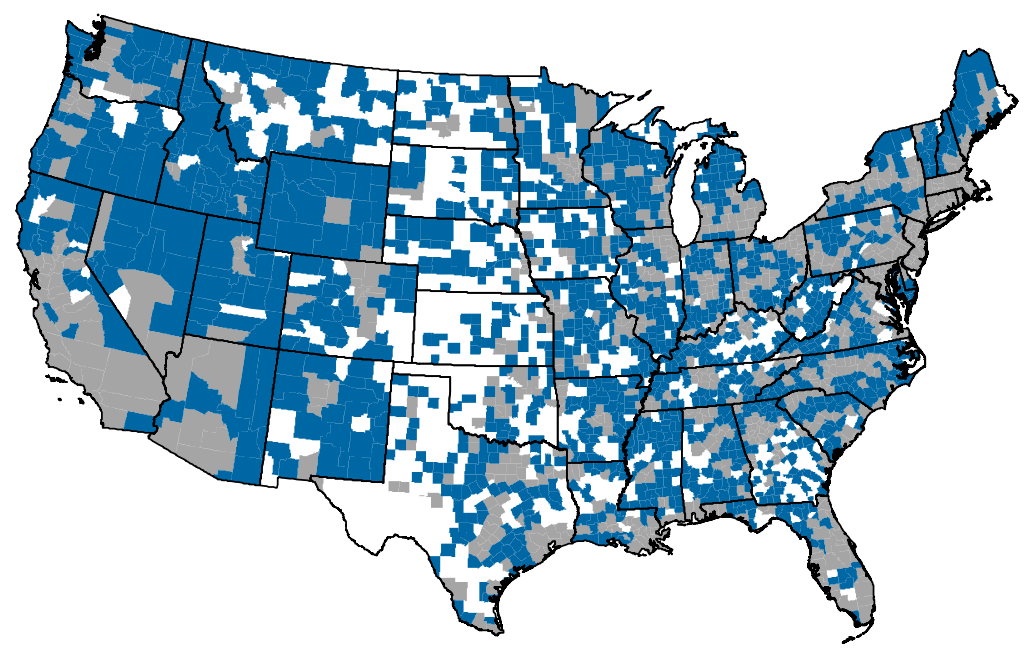

Not Present At Least One

MSA

Note: Regional banking organizations are those with total deposits indexed to $\$ 1$ billion or more as of June 1998.

concentrate their offices in the rural counties with relatively high population density-where they can serve relatively large numbers of customers from each office - the many rural counties with lower population density would be relatively isolated from the effects of competition from large banking organizations.

Tables 3 and 4 indicate that the association between population density and the presence of large banking organizations depends on how long the states have permitted statewide branching. In the rural counties of states that prohibited statewide branching during 1980, large organizations have establ ished offices and have become the major banking organizations primarily in the rural counties with relatively high population density. Table 3 indicates that in these states, large organizations (total deposits in excess of $\$ 10$ billion) had offices in 95 percent of the counties with population over 100 per square mile during 1999, but had offices in only 27 percent of the counties with population density below 25. Table 4 indicates that in the states that prohibited statewide branching in 1980, the rural counties where large organizations accounted for 50 percent or more of local deposits were primarily the counties with relatively high population density. Large organizations have a greater presence in the rural counties with low population density in the states that permitted statewide branching during 1980. The evidence in Tables 3 and 4 is consistent with the conclusion that low population density is not a barrier to the entry by large banking organizations into rural communities. The presence of large banking organizations in rural counties of the states that prohibited statewide branching during 1980 appears to be in the process of becoming more like that in the states that permitted statewide branching during 1980.

\section{CONCLUSIONS}

Economic research has not produced a consensus on how the offices of large banking organizations affect rural communities. The objective of this article is to examine patterns in the presence of large organizations in rural communities. This information might provide a foundation for future research. 


\section{Presence of Large Banking Organizations in Rural Counties}

1980
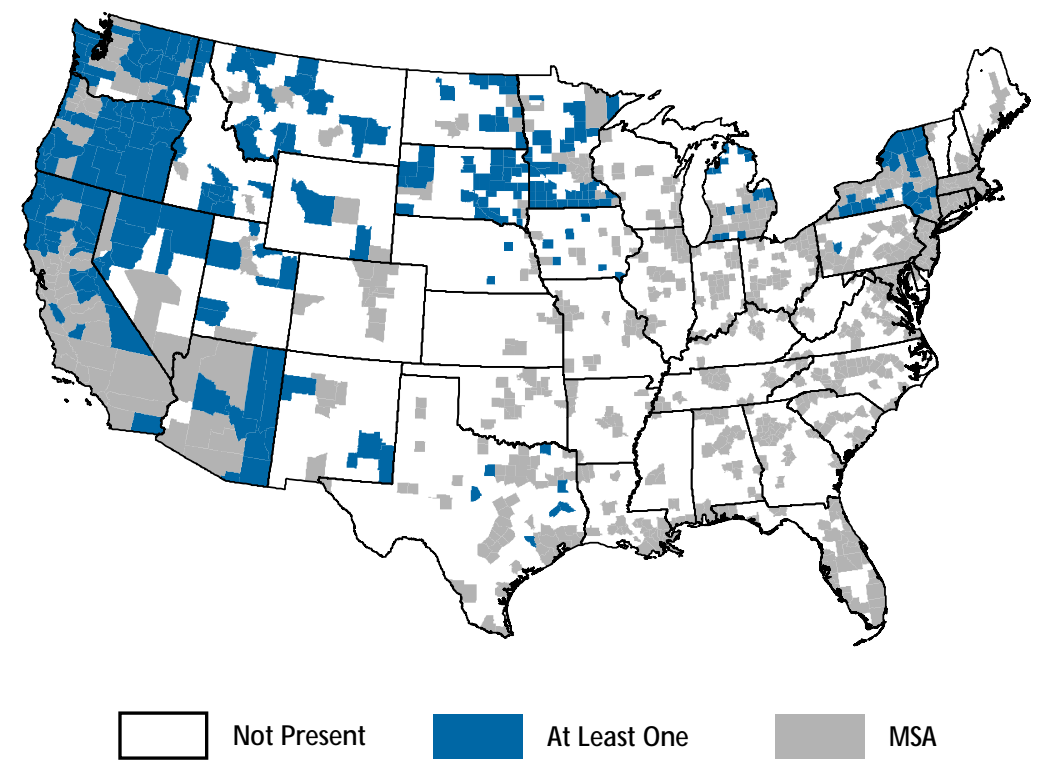

Note: Large banking organizations are those with total deposits indexed to $\$ 10$ billion or more as of June 1998.

The presence of large banking organizations in the rural areas of a state reflects the state's regulation of branch banking as far back as 1980. During 1980, large organizations had very limited presence in the rural counties of the states that placed the greatest restrictions on branch banking. Large organizations had much more substantial presence in the rural counties of the states that permitted statewide branching. This association between state branching restrictions and the presence of large banks in rural areas during 1980 holds after adjusting for the differences in population density among rural counties. This contrast among the states during 1980 indicates that large organizations had the interest and ability to compete in rural areas where they were given permission to establish branches throughout their states.

The relaxation of regulations about where holding companies may buy banks and the relaxation of branch banking regulations since 1980 have facilitated the entry of large banking organizations into many rural communities. As of June 1999, most rural residents lived in counties where large organizations had at least one office. The expansion of large banking organizations in rural areas accelerated after nationwide interstate banking became legal under federal legislation during the fall of 1995. Large banking organizations acquired offices in rural areas in recent years by acquiring smaller, regional organizations that had established their networks of rural banking offices prior to federal legislation on nationwide interstate banking.

While nationwide branch banking has facilitated the entry of large banking organizations into many rural communities, the large organizations have not become the dominant banks in most of the rural counties where they have established offices. As of June 1999, the rural counties where large organizations accounted for half or more of local deposits were located primarily in the West-where large banks have been the major organizations in rural counties for many years. Outside of the western regions, most rural residents lived in counties where large organizations accounted for less than half of local deposits.

In the states that prohibited statewide branching during 1980, entry by large organizations has been concentrated primarily in the rural counties with rel- 


\section{Figure 2b}

1995

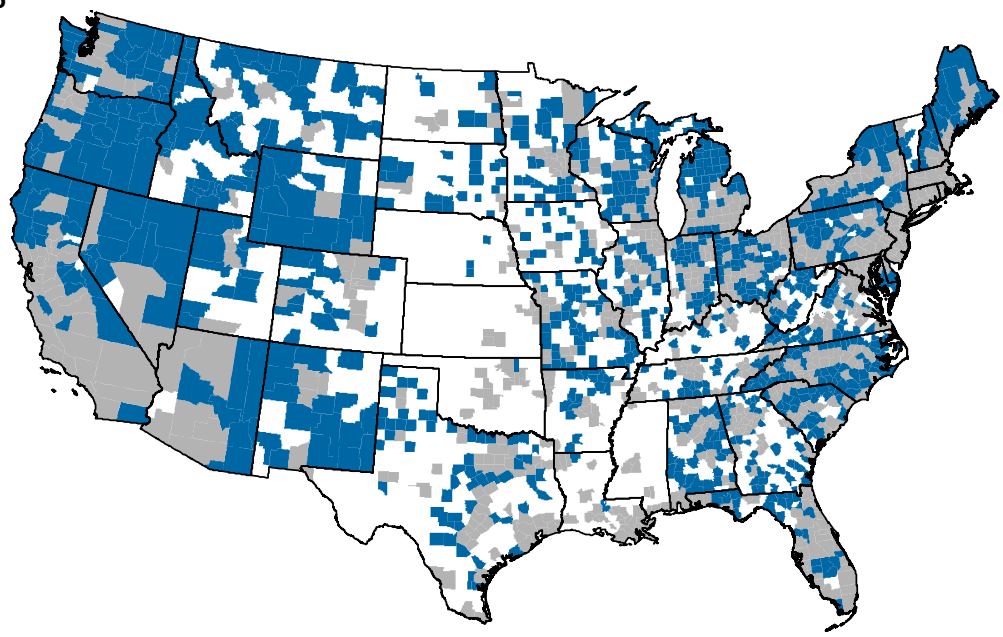

Not Present $\quad$ At Least One

MSA

Note: Large banking organizations are those with total deposits indexed to $\$ 10$ billion or more as of June 1998.

\section{Figure 2c}

1999

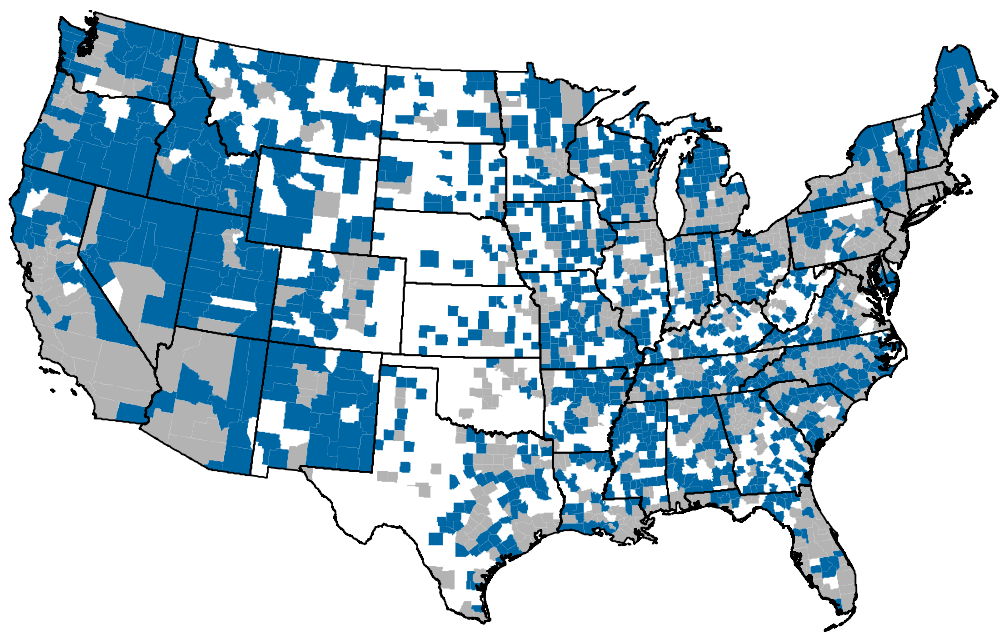

Not Present $\quad$ At Least One

MSA

Note: Large banking organizations are those with total deposits indexed to $\$ 10$ billion or more as of June 1998. 
Table 3

\section{Association Between Population Density and the Presence of Large Banking Organizations} in Rural Counties

States that permitted statewide branching in 1980
States that did not permit statewide branching in 1980

\section{Population per square mile}

Banks with total deposits (in billions of dollars) indexed to 1998 greater than:

$\$ 10$

$\$ 1$

$\$ 5$

$\$ 10$

Percent of rural counties in which large banks had at least one office.

1980

0 to 25

25 to 50

50 to 75

75 to 100

Over 100

74.1

75.3

62.4

50.6

54.0

47.1

64.5

88.2

100.0

77.8

69.3

96.0

100.0

75 to 100

100.0

100.0

65.8

87.3

95.9

100.0

100.0

100.0

100.0

100.0

76.6

96.2

65.8

88.6

95.9

100.0

100.0

100.0
63.0

82.1

92.0

100.0

100.0

53.8

36.4

24.0

17.6

16.1

65.2

78.5

91.8

96.2

97.4

65.8

82.3

91.8

100.0

100.0
18.1

22.7

32.1

40.0

52.3

39.8

61.9

82.7

87.5

96.7

43.9

68.8

82.0

92.0

98.4

45.1

72.0

85.7

94.0

100.0

\section{0}

9.9

18.7

18.9

36.9

27.0

21.1

34.6

57.3

64.4

84.3

$90.9 \quad 84.3$

Over 100

100.0

Note: The following states permitted statewide branching in 1980, subject to various restrictions on branching in the communities where banks had their headquarters: Alaska, Arizona, California, Connecticut, Delaware, Hawaii, Idaho, Maine, Maryland, Nevada, New Hampshire, New Jersey, New York, North Carolina, Oregon, Rhode Island, South Carolina, South Dakota, Vermont, and Washington. 
Table 4

Association Between Population Density on the Location of Rural Counties Where Large Banking Organizations Were the Major Banks

States that permitted statewide branching in 1980

States that did not permit statewide branching in 1980

Population
per square
mile

Banks with total deposits (in billions of dollars) indexed to 1998 greater than:

$\$ 1 \quad \$ 5 \quad \$ 10 \quad \$ 1 \quad \$ 5 \quad \$ 10$

1980

0 to 25

25 to 50

50 to 75

75 to 100

Over 100

1995

0 to 25

25 to 50

50 to 75

75 to 100

Over 100

1998

0 to 25

25 to 50

50 to 75

75 to 100

Over 100

1999

0 to 25

25 to 50

50 to 75

75 to 100

Over 100

$\begin{array}{rr}58.4 & 43.9 \\ 50.6 & 23.4 \\ 60.0 & 14.0 \\ 58.8 & 0.0 \\ 64.5 & 9.7\end{array}$

56.2

65.4

74.0

79.2

83.8

52.3

62.0

75.5

84.6

89.7

52.8

63.3

71.4

84.6

87.2
47.3

51.3

54.0

54.2

67.6

40.6

51.9

44.9

73.1

87.2

40.6

51.9

46.9

73.1

87.2

29.9
10.4
4.0
0.0
3.2

32.3

30.8

38.0

33.3

54.1

37.1

35.4

32.7

30.8

51.3

39.1

39.2

32.7

34.6

51.3
8.0

7.2

13.4

12.6

20.7

15.1

18.5

38.2

42.3

62.0

16.7

22.1

39.3

44.0

61.2

16.0

23.9

39.8

39.0

58.9
4.1

1.5

4.8

4.2

9.0

8.2

9.9

23.1

22.1

39.7

9.7

11.5

21.3

19.0

34.9

8.7

7.7

11.5

20.1

13.0

37.2

2.3

0.5

2.4

2.1

0.0

5.2

5.5

13.8

15.4

26.4

7.4

8.6

13.1

13.0

28.7
Note: See Table 3 for the list of states that permitted statewide branching in 1980. 


\section{Figure 3a}

Rural Counties Where Large Banks Were the Major Organizations in June 1999

Large Organizations Accounted for 50 Percent or More of Local Deposits

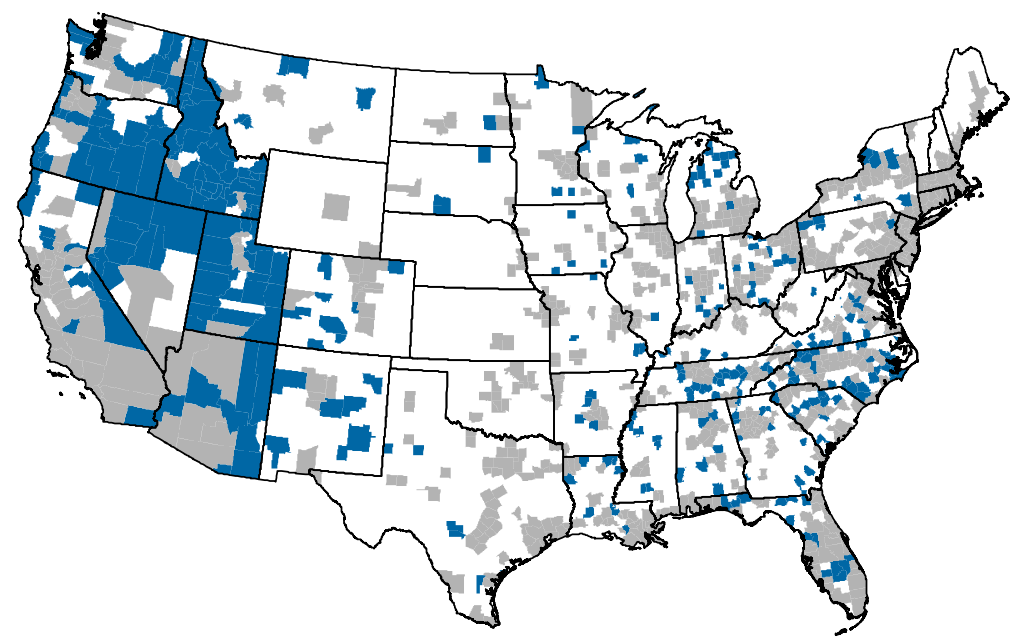

Less than $50 \%$ of Deposits

More than $50 \%$ of Deposits

MSA

Note: Large banking organizations are those with total deposits indexed to $\$ 10$ billion or more as of June 1998.

\section{Figure 3b}

Large Organizations Accounted for 90 Percent or More of Local Deposits

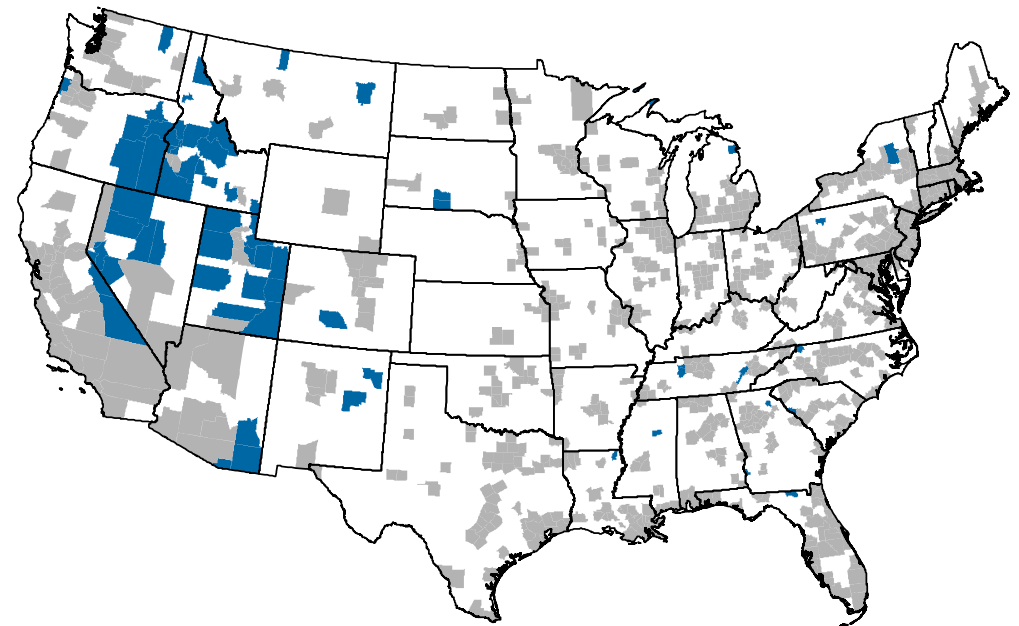

Less than $90 \%$ of Deposits

More than $90 \%$ of Deposits

MSA

Note: Large banking organizations are those with total deposits indexed to $\$ 10$ billion or more as of June 1998. 
atively high population density. If we focused on these states alone, we might conclude that low population density is an effective barrier to entry by large organizations. In the states that permitted statewide branching as early as 1980, however, the association between the presence of large organizations and population density is much less pronounced. This contrast indicates that the entry of large organizations into rural areas is still in transition in the states that liberalized branching restrictions more recently. Over time, we can expect the association between population density and the presence of large banking organizations in rural communities to become less pronounced in the states that liberalized their branching regulations more recently. For small, locally owned banks in rural areas, low population density is not an effective barrier to the entry by large banking organizations into their communities.

\section{REFERENCES}

Berger, Allen N., Rebecca S. Demsetz, and P.E. Strahan. “The Consolidation of the Financial Services Industry: Causes, Consequences, and Implications for the Future," Journal of Banking and Finance (February 1999), pp. 135-94.

, Anil K. Kashyap, and Joseph M. Scalise. "The Transformation of the U.S. Banking Industry: What a Long, Strange Trip It's Been," Brookings Papers on Economic Activity (1995:2), pp. 55-218.

, Anthony Saunders, Joseph M. Scalise, and Gregory F. Udell. "The Effects of Bank Mergers and Acquisitions on Small Business Lending," Journal of Financial Economics (November 1998), pp. 187-229.

and Gregory F. Udell. “The Economics of Small Business Finance: The Roles of Private Equity and Debt Markets in the Financial Growth Cycle," Journal of Banking and Finance (August 1998), pp. 613-73.

Calomiris, Charles W. "Regulation, Industrial Structure, and Instability in U.S. Banking: An Historical Perspective," in Structural Change in Banking, Michael Klausner and Lawrence J. White, eds., Business One Irwin, 1993, pp. 19-116.

Cole, Rebel A., and John D. Wolken. "Financial Services Used by Small Businesses: Evidence from the 1993 National Survey of Small Business Finances," Federal Reserve Bulletin (July 1995), pp. 629-67. , and R. Louise Woodburn. “Bank and Nonbank Competition for Small Business Credit: Evidence from the 1987 and 1993 National Surveys of Small Business Finances," Federal Reserve Bulletin (November 1996), pp. 983-95.
Elliehausen, Gregory E., and John D. Wolken. “Banking Markets and the Use of Financial Services by Small and Medium-Sized Businesses," Board of Governors Staff Study 160, September 1990.

Evanoff, Douglas D. "Branch Banking and Service Accessibility," Journal of Money, Credit, and Banking (May 1988), pp. 191-202.

Featherstone, Allen M. "Post-Acquisition Performance of Rural Banks," American Journal of Agricultural Economics (August 1996), pp. 728-33.

Gilbert, R. Alton. "Implications of Banking Consolidation for the Financing of Rural America," in Financing Rural America, Federal Reserve Bank of Kansas City, April 1997, pp. 131-40.

and Michael T. Belongia. "The Effects of Affiliation with Large Bank Holding Companies on Commercial Bank Lending to Agriculture," American Journal of Agricultural Economics (February 1988), pp. 69-78.

and Levis A. Kochin. "Local Economic Effects of Bank Failures," Journal of Financial Services Research (December 1989), pp. 333-45.

Gunther, Jeffrey W. "Geographic Liberalization and the Accessibility of Banking Services in Rural Areas," Financial Industry Studies Working Paper No. 1-97, Federal Reserve Bank of Dallas, February 1997.

Jayaratne, Jith, and Philip E. Strahan. "The Finance-Growth Nexus: Evidence from Bank Branch Deregulation," Quarterly Journal of Economics (August 1996), pp. 639-70.

and John Wolken. "How Important are Small Banks to Small Business Lending? New Evidence from a Survey of Small Firms," Journal of Banking and Finance (February 1999), pp. 427-58.

Keeton, William R. “Do Bank Mergers Reduce Lending to Businesses and Farmers? New Evidence from Tenth District States," Federal Reserve Bank of Kansas City Economic Review (Third Quarter 1996), pp. 63-75.

Lawrence, David B., and Marie R. Klugman. "Interstate Banking in Rural Markets: The Evidence from the Corn Belt," Journal of Banking and Finance (December 1991), pp. 1081-91.

Neff, David L., and Paul N. Ellinger. "Participants in Rural Bank Consolidations," American Journal of Agricultural Economics (August 1996), pp. 721-27. 